"Immigration and the Life Course," special issue, Canadian Studies in Population 40, no. 1-2 (2013): 23-34.

\title{
Job matching for Chinese and Asian Indian immigrants in Canada
}

\author{
Eric Fong \\ Department of Sociology, University of Toronto \\ fong@chass.utoronto.ca \\ Peter Shi Jiao \\ Statistics Canada
}

\begin{abstract}
Using recently collected data from Toronto, a major city in Canada, we explored job mismatch among Chinese and Asian Indian immigrants. Our study shows that a relatively small percentage of Chinese immigrants, and an even lower percentage of Asian Indian immigrants, work in the same industry and occupation as they did before immigrating. The multivariate analysis suggests that higher education before immigration does help immigrants secure first jobs that match their jobs before immigration. Though other studies have noted that foreign education has a discount effect on earnings and on securing jobs, our findings show that foreign higher education improves the matching of jobs held before and after immigration. Implications of the findings are discussed.
\end{abstract}

Keywords: job mismatch; Chinese immigrants; Asian Indian immigrants.

\section{Résumé}

Au moyen de données recueillies récemment à Toronto, nous avons examiné le mauvais jumelage d'emplois chez. les immigrants chinois et indiens d'Asie. Notre étude démontre qu'un pourcentage relativement petit d'immigrants chinois travaille dans le même secteur et le même métier qu'avant d'immigrer. Chez, les immigrants indiens d'Asie, ce pourcentage est encore plus petit. L'analyse multidimensionnelle indique que les immigrants qui possèdent un niveau de scolarité plus élevé à leur arrivée au pays les aident à obtenir un emploi correspondant à celui qu'ils occupaient avant d'immigrer. Bien que d'autres études aient démontré qu'une éducation à l'étranger a un mauvais effet sur les revenus et les possibilités d'emploi, nous avons constaté qu'une meilleure scolarité à l'étranger améliorait les chances de trouver un emploi dans le secteur qu'avant l'immigration. Les implications de ces conclusions sont discutées dans l'article.

Mots-clés : mauvais jumelage d'emplois, immigrants chinois, immigrants indiens d'Asie.

\section{Introduction}

The media frequently report that immigrants face employment problems that lead to skill mismatch (CampionSmith 2005; Reitz 2011). They report that many immigrants do not work in the same types of jobs that they held in their home countries. Thus, there are stories of immigrant scientists driving taxis or working in computer sales, or immigrants with senior administrative experience working in restaurants as servers. Despite the widespread image of immigrants in job mismatches, there is not a lot of detailed information. One of the major reasons for the lack of data is that job mismatch information about immigrants is seldom available. Some studies have addressed specific occupations, such as engineering (Boyd 2001; Tang 1993). For example, Boyd and Thomas (2001) showed that job mismatch in the first few years for immigrants with engineering training is more common than for Canadian-born engineers.

Despite the paucity of information on job mismatch among immigrants, the topic has significant implications. First, the study of job mismatch views the adaptation of immigrants in a new country as part of a life course experience that can be traced back to the migrant's life before immigration. Most studies of immigrant adaptation do not consider experiences before immigration (Alba and Nee 1997; Bean and Stevens 2003; White and Glick 2009). Immigrant adaptation tends to be seen as a consequence of experiences and resources held after arrival in the new country. The study of job mismatch recognizes that immigrant adaptation is also affected by life course experiences before 
immigration. It opens a window to understand how experiences before immigration contribute to experiences after immigration. Second, job mismatch suggests possible skill mismatch, i.e., that immigrants are not able to fully utilize their training and work experience, and that their human capital is not fully used for the benefit of productivity in the labour market of their new country (Bean et al. 1996; Li 2000). Third, job mismatch suggests that immigrants face a "bumpy" road towards economic integration (Gans 1997), that they may have to switch jobs a number of times in order to match their prior training and work experience, and that in the process they may feel frustration or disappointment (Constant and Massey 2002; DaVanzo and Morrison 1981). Some of them eventually decide to return to their home countries (Shibuya et al. 2001). Thus, the job mismatch situation can affect the integration of immigrants.

In this paper, we explore the job mismatch among immigrants, a topic which envisages that immigrant adaptation should be studied from a life course perspective even before immigration (Kim 2008; Salaff et al. 2010). Using data collected in 2006 that include information about jobs before and after immigration and job history after immigration, the study focuses on the job mismatch of Chinese and Asian Indians in Toronto, the two major immigrant groups in the country. The study contributes to the literature in two ways. First, it documents the extent of mismatch between first and current jobs. To the best of our knowledge, this is the first study to document the mismatch situation of immigrants in these two groups. The second part of the study explores how the likelihood of job mismatch is affected by three sets of factors related to experiences before immigration, at the time of immigration, and after immigration. In particular, we focus on education received overseas before immigration, age at immigration, and the occupation and industry involved after immigration. Our study provides a perspective on these factors and their relative effects on job mismatch for immigrants.

Our analysis indicates that among currently employed immigrants, the likelihood of finding employment comparable to their employment in the home country is affected by university education, even if completed overseas, and the type of occupation in which they worked previously. Looking only at the first job after immigration, we find that university education, especially if received overseas, affects the job matching of immigrants who did not experience subsequent job changes. The effect is not significant for the job match of the first job when there were subsequent changes.

\section{Literature review}

To understand the job mismatch patterns of immigrants, we focus on three different factors that relate to their experiences before immigration, at the time of immigration, and after immigration: 1) the effects of education before immigration (Fong and Cao 2009; Li 2001; Zeng and Xie 2004), 2) age at immigration (Rumbaut 2004; Sakamoto et al. 2009), and 3) occupation and industrial sectors involved after immigration (Piore 1979; Sanders and Nee 1987; Tang 1993). It has been well documented in the literature that these factors can have detrimental effects on the economic attainments of immigrants. However, their effects on job match have not been well studied. In addition, education before immigration, and occupation and industrial sectors involved after immigration, reflect the institutional effects on economic attainment among immigrants. Recent studies have pointed out the importance of institutional arrangements to immigrant adaptation (Alba and Nee 2003; White and Glick 2009).

\section{Before immigration: Effect of foreign education}

Today's labour market places a great emphasis on credentials, which represent education-based skills (Bell 1973; Farley 1996; Santiago 1993). Canada's knowledge-based economy is largely driven by information and communication technologies, as well as financial sectors, all of which require advanced skills and education (Baldwin and Beckstead 2003). In other words, employment success is increasingly determined by high educational attainment. Immigrants are not exempt from this reality. Studies have documented that a higher level of education, even if received overseas before immigration, is related to better labour market outcomes for immigrants (Zeng and Xie 2004).

Though most studies have observed that level of education can have direct positive effect on job attainment among immigrants, some recent studies also have noted the discount effect of the level of foreign education before immigration on immigrants' labour market experiences (Belman and Heywood 1991; Zeng and Xie 2004).

The discount effect of foreign education suggested by some researchers is related to a set of skills in job search and knowledge of the job market associated with the education received (Behrman et al. 1996). These skills and knowledge include interaction skills, expectations, or information about the labour market (Card and Krueger 1992). 
Fong and Jiao: Job matching for Chinese and Asian Indian immigrants in Canada

They are helpful in job searches, which in turn can translate into higher earnings. Since most of these skills and knowledge are location-specific, those attained as part of a foreign education may not be easily transferred to another country. In contrast, the skills and knowledge associated with education in the host country are more readily translated to the local labour market. Subsequently, immigrants who received their foreign education before immigration may have more difficultly finding jobs to match their previous experience.

The discount effect of foreign education is also related to the screening mechanisms in job search. Drawing from the literature of education on screening theories, labour economists (Belman and Heywood 1991; Park 1999) have observed that employers perceive levels of education as indicators of certain levels of productivity. Employers recruit workers according to level of education, and the market rewards them accordingly (Jaeger and Page 1996). However, employers usually know little about foreign educational systems or about universities overseas. They are reluctant to recruit immigrants who received their education overseas. These concerns have direct and significant implications for understanding the job mismatch of immigrants with foreign education, especially for those who completed university overseas.

In short, there are two sets of suggestions about the effects of foreign education before immigration on job match among immigrants. One set of arguments suggests that higher education increases competitiveness in the labour market, regardless of whether it was received in foreign countries. Therefore, job match of immigrants would not be affected. Another set of literature argues that higher education received overseas before immigration may increase the likelihood of job mismatch among immigrants.

\section{At immigration: Age at immigration}

From a life course perspective, the age at which immigrants arrive in the country can have considerable effect on their subsequent integration (Kim and Sakamoto 2010; Lee and Edmonston 2011; Rumbaut 2008; Myers and Cranford 1998; Myers et al. 2009). Despite variations in understanding the process, most studies, especially those drawn from studies of the 1.5 generation of immigrants, agree that immigrants who arrive at an earlier age have better adjustment outcomes than those who arrived in the country at an older age (Kim and Sakamoto 2010; Portes and Schauffler 1994). Subsequently, their economic achievements are better off.

To translate this result to the job mismatch patterns of immigrants, we expect that immigrants who arrive at a younger age will be less likely to experience job mismatch than those who come at a later age. From the supply side of the labour market, immigrants who arrived at an earlier age usually are more familiar with the labour market and have larger networks to obtain more information about job availability. From the demand side of the labour market, local employers may find that those who arrived at a younger age are more ready to contribute to their job with less training. These immigrants may be considered to be more knowledgeable about the local society and labour market. At the same time, they may find that immigrants who arrived at an older age later come with a set of job expectations from their home country that may not be applicable to the new country.

However, some studies show different pictures. These studies argued that the initial disadvantage in the labour market of the new country of immigrants who arrived later may be offset as they live in the country longer and learn more about the labour market. Evidence presented by Li (2003) in Canada using data from the Longitudinal Immigration Database (IMDB) suggests that although more recent immigrant cohorts have lower initial earnings than previous cohorts, they "catch up" to native-born workers over time at a faster rate. Similarly, Boyd and Thomas (2001) showed that immigrants with engineering training are more likely to find jobs in their former industries after they have lived a while in the new country. These findings indicate that job experiences in the old country may help immigrants who came at an older age to adapt quickly to the new working environment. Therefore, age at immigration becomes less important to the job-matching of immigrants in subsequent job changes.

The literature implies two sets of relationship between age at immigration and job mismatch. One set of literature suggests that immigrants who arrive at an older age are more likely to experience job mismatch, while another set argues that they are not.

\section{After immigration: Occupational type and industrial sector}

DaVanzo and Morrison (1981) observed that not all human capital is transferable. Some forms of capital are more difficult to transfer than others. They suggested that immigrants with capital that is not transferable would encounter more difficulty securing jobs comparable to their jobs in the home country. Compounding the fact that some occupational and industrial sectors have set their own institutional criteria to control the supply of workers who 
are qualified, immigrants with these job backgrounds may have difficulties finding jobs that match their previous job experience.

Job matching is especially a challenge for administrative and financial occupational sectors and for professional, scientific, and technical industrial sectors that require local credentials (Jaeger and Page 1996; Li 2001). Jobs in these occupational and industrial sectors usually have strict standards and requirements set by local associations (Reitz 2011; Reitz 1999). Even immigrants with relevant training in their home countries are often required to take qualifying examinations to obtain local licenses. As a result, only those immigrants with such backgrounds who are familiar with the examination system or have time to prepare for the examinations will secure jobs in these industrial and occupational sectors.

Studies of foreign-trained professionals have consistently shown that they have difficulty finding jobs that match their employment background before immigration (Gans 2009). Ethnographic studies of immigrant economic adaptation usually repeat the same theme that some jobs are difficult to obtain because of the requirements for credentials set by the associations of the industrial and occupational sectors (Park 1997; Zhou 1992). Findings from the Longitudinal Survey of Immigrants to Canada (Statistics Canada 2001) note a shift from higher-skilled occupations pre-migration to lower-skilled occupational groups post-migration. Most of these higher-skilled occupations are in professional, scientific, and technical sectors or in administrative and financial occupational sectors. Similar patterns are reported in a study by Bhandari et al. (2006) of highly skilled men in Calgary. He found that, faced with nonrecognition of foreign credentials and work experience, immigrants were forced to take "survival jobs," which were low-paying and did not utilize their education or work experience. These results further echo the findings that there has recently been an increase in immigrants who after their arrival in Canada work in "sales and service occupations" and "occupations unique to processing, manufacturing, and utilities."

We expect that immigrants in administrative and financial sectors and in professional, scientific, and technical industrial sectors will be less likely to have job mismatch, while immigrants in "sales and service occupations" and “occupations unique to processing, manufacturing, and utilities" will more likely experience job mismatch.

In summary, we suggest that three factors related to before immigration, at immigration, and after immigration can affect the job match of immigrants. Some factors (e.g., effects of foreign education and age at immigration) have been suggested to have different effects on job mismatch among immigrants. In the following analysis, we explored the job match situation of Chinese and Asian Indian immigrants, using a recent dataset collected in Toronto, a major city in Canada.

\section{Data and methods}

The data for this study were taken from the New Economy and Immigrant Adaptation Survey, a telephone survey conducted in Toronto in 2005. The survey contains 784 Chinese and Asian Indian immigrant respondents, representing the two largest immigrant groups in Toronto. The study focuses on their job match situations. The survey contains information on the job history of the respondents before immigration and up to seven of their jobs after immigration. It also includes socio-demographic data and detailed information about their current jobs.

To explore their job match patterns, we focus on the match between the occupation and/or industry of respondents' jobs before immigration and the occupation and/or industry of their jobs after immigration. We emphasize both occupation and industry, because occupation matching shows the transferability of specific skills and qualifications, and industry matching suggests the transferability of industrial knowledge. Therefore, we explore the matching of occupational type, the matching of industrial sector, and the matching of both.

Individual responses to questions regarding occupational types are coded according to standardized codes listed in the 2001 National Occupational Classification (NOC-S). Individual responses to questions regarding industrial sector are coded according to standardized codes listed in the 2002 North American Industry Classification System (NAICS). NOC-S is developed by Human Resources and Skills Development Canada. ${ }^{1}$ Our definitions of occupational types are based on 2-digit occupation codes. There are about 140 categories of occupations. NAICS is developed by the statistical agencies of Canada, United States, and Mexico. ${ }^{2}$ Definitions of industrial sectors are based

1. http://www.statcan.gc.ca/subjects-sujets/standard-norme/soc-cnp/2001/noc2001-cnp2001-menu-eng.htm.

2. http://www.statcan.gc.ca/subjects-sujets/standard-norme/naics-scian/2002/naics-scian02l-eng.htm. 
Fong and Jiao: Job matching for Chinese and Asian Indian immigrants in Canada

on 2-digit industry codes. About 24 industries are included. Both occupational and industrial categories can be too broad, especially the industrial categories. Therefore, the interpretation of the results should be cautious.

Like most workers, most immigrants change jobs over time. Each job change represents a better or worse fit with the job held prior to immigration. Therefore, to consider fully the life course of job attainments since arrival, we explored three scenarios for immigrants' job changes. First, we considered the match of the occupation and/or industry of the current job with the job before immigration. The current job may be the first job since immigration or the job obtained after several job changes since arrival in Canada. Taking a cross-sectional perspective provides a general overview of the job match situation. After limiting our sub-sample to only those respondents who were currently employed and who also had been employed before immigration, the sub-sample was reduced to 231 respondents.

Second, we looked at the first job of those who have had only one job since immigration. In this set of analysis, we also included those who do not currently have jobs. They may be retired or looking for work. After limiting the sub-sample to those who have had only one job since immigration and were employed before immigration, the number of cases is 142 respondents. This number suggests that almost half the respondents have never changed jobs since their arrival.

Third, we studied the first job of those who have had two jobs or more since immigration. Changing jobs may indicate job instability, or that the first job was not desirable. We want to understand whether these early jobs matched the jobs held before immigration. Similarly, we included those who do not currently have jobs. The size of this subsample is 89 .

The binary dependent variables are assigned a value of 1 , based on a match between the job before immigration and the job after immigration on one or both of the dimensions in a particular scenario, and 0 if there is a mismatch.

\section{Independent variables}

\section{Before immigration: Effect of foreign education}

We developed a set of dummy variables to categorize respondents into three groups: those who completed university education overseas, those who completed university education in Canada, and those who did not complete university education. The contrast category is those who did not complete university education. Previous studies have suggested that the discount effect is stronger among those who completed university overseas (Jaeger and Page 1996).

\section{At immigration: Age at immigration}

This variable is computed by subtracting the year at which the respondent immigrated from the age of the respondent in 2005, when the survey was conducted.

\section{After immigration: Occupation and industry}

Our dependent variable for capturing job mismatch is based on the 2-digit categories of the occupational and industrial classifications. For the independent variable, we collapsed these categories into the three largest categories shared by respondents for each classification. The purpose is to minimize problems that might arise in the analysis due to small numbers in some of the occupational and industrial categories as independent variables. The occupation dummy variable that is created, in reference to the 2001 National Occupational Classification (NOC-S), comprises the following categories: (1) Business, Finance and Administrative Occupations; (2) Sales and Service Occupations; and (3) Occupations Unique to Processing, Manufacturing, and Utilities. A large proportion of Chinese and Asian Indian immigrants work in these three occupational categories. All other occupational categories are coded as 0 , which serves as the reference group. The industry dummy variable that is created, in reference to the 2002 North American Industry Classification System (NAICS), comprises the following categories: (1) Manufacturing and Construction; (2) Professional, Scientific, and Technical Services; and (3) Educational Services. These categories were chosen because many Chinese and Asian Indians are involved in these industrial sectors. All other industrial categories are coded as 0, which serves as the reference group. We understand both industrial and occupational categories are board. 


\section{Other independent variables}

In addition to these major independent variables, we also include other demographic variables in the analysis. A gender dummy variable is coded as 1 if the respondent is female and 0 if male. Lastly, we include a dummy variable to distinguish between Chinese and Asian Indian immigrants, with Chinese being coded as 1 and Asian Indians as 0 .

\section{Additional information about the current job}

Our analysis of the current job mismatch includes some additional information because it is available. Duration in Canada is included in the analysis to capture any possible integration effect. Immigrants who have been in the country longer are more likely to obtain more information and to know more about the operations and expectations of the job market. The variable is computed by subtracting the year the respondent immigrated to Canada from 2005.

Also included is information on whether or not the respondent is a supervisor at the current job, whether or not English is used, and whether the majority of co-workers, clients, and managers are co-ethnic. (If more than 40 per cent of co-workers, clients, and managers are co-ethnic, the respondent is probably working in an ethnic economy.) Lastly, the survey provides information about how respondents found their current jobs. The role of social networks in finding jobs is well documented in the literature (Granovetter 1973; Montgomery 1992). Respondents who indicate they found their jobs through co-ethnic friends are coded as 1 , and 0 otherwise. This information helps us to better understand the match or mismatch of the current job.

Analysis of the various job match scenarios was conducted using logistic regression. Having the same occupation, industry, or both in the current job as in the job before immigration as is coded as 1 , otherwise 0 . We use the same coding for the analysis of the first job, whether or not there were subsequent changes.

Table 1 provides descriptive statistics for the variables included in the analysis. We compared our data with the 2006 census. Because only a few variables in our data are comparable with census variables, we did not include a column to report census information. Instead, we report the information in the following discussion.

Though we select immigrants who are living and currently employed in the Toronto CMA, the census data collection was one year different from our survey and reports South Asians, while our survey includes only Asian Indians. Despite these differences, our sample is very similar to the census data. While our sample is 51 per cent female, the census indicates females to be about 45 per cent of South Asians and Chinese. In addition, Chinese represent 58 per cent of the sample, while in the census Chinese are about 46 per cent when grouped with all South Asians. Finally, the average age at immigration of respondents in the survey is older, about 33 years old. The census reports that the median age of Chinese and South Asian immigrants is between 25 and 29.

Table 1. Descriptive statistics of the analysis sample.

\begin{tabular}{lrcr}
\hline & $\mathrm{N}$ & $\%$ & Median \\
\cline { 2 - 4 } University Education Before Immigration & 139 & 60.2 & \\
Age at Immigration & 231 & & 33 \\
Female & 117 & 50.6 & \\
University Education After Immigration & 27 & 11.7 & \\
Duration in Canada & 231 & & 13 \\
Chinese & 135 & 58.4 & \\
Current Job Found Through Ethnic Ties & 61 & 26.4 & \\
Supervisor At Current Work & 55 & 23.8 & \\
English Use at Current Work & 193 & 83.5 & \\
Majority of Current Coworkers Co-Ethnic & 63 & 27.3 & \\
Majority of Current Clients Co-Ethnic & 36 & 15.6 & \\
Majority of Current Managers Co-Ethnic & 45 & 19.5 & \\
\hline Total Number & 231 & & \\
\hline
\end{tabular}


Fong and Jiao: Job matching for Chinese and Asian Indian immigrants in Canada

Table 2. Descriptive Statistics for Current or First Job for Chinese and Asian Indian Immigrants.

\begin{tabular}{|c|c|c|c|c|c|c|c|c|c|c|}
\hline \multirow{4}{*}{$\begin{array}{l}\text { Occupation and industry the } \\
\text { same as before immigration }\end{array}$} & & \multicolumn{3}{|c|}{ Current job } & \multicolumn{3}{|c|}{$\begin{array}{l}\text { First job without } \\
\text { subsequent change }\end{array}$} & \multicolumn{3}{|c|}{$\begin{array}{l}\text { First job with } \\
\text { subsequent change }\end{array}$} \\
\hline & & Chinese & $\begin{array}{l}\text { Asian } \\
\text { Indian }\end{array}$ & Total & Chinese & $\begin{array}{l}\text { Asian } \\
\text { Indian }\end{array}$ & Total & Chinese & $\begin{array}{l}\text { Asian } \\
\text { Indian }\end{array}$ & Total \\
\hline & $\%$ & 24.4 & 16.7 & 21.2 & 29.8 & 22.5 & 26.8 & 8.5 & 10.8 & 9.5 \\
\hline & $\mathrm{N}$ & 33 & 16 & 49 & 25 & 13 & 38 & 4 & 4 & 8 \\
\hline \multirow{2}{*}{$\begin{array}{l}\text { Occupation the same as } \\
\text { before immigration }\end{array}$} & $\%$ & 34.8 & 26.0 & 31.2 & 41.7 & 29.3 & 36.6 & 14.9 & 16.2 & 15.5 \\
\hline & $\mathrm{N}$ & 47 & 25 & 72 & 35 & 17 & 52 & 7 & 6 & 13 \\
\hline \multirow{2}{*}{$\begin{array}{l}\text { Industry the same as before } \\
\text { immigration }\end{array}$} & $\%$ & 37.8 & 30.2 & 34.6 & 44.1 & 36.1 & 40.9 & 17.0 & 21.6 & 19.0 \\
\hline & $\mathrm{N}$ & 51 & 29 & 80 & 37 & 21 & 58 & 8 & 8 & 16 \\
\hline \multirow{2}{*}{$\begin{array}{l}\text { Neither occupation nor } \\
\text { industry is the same as } \\
\text { before immigration }\end{array}$} & $\%$ & 51.9 & 60.4 & 55.4 & 44.1 & 56.9 & 49.3 & 76.6 & 73.0 & 75.0 \\
\hline & $\mathrm{N}$ & 70 & 58 & 128 & 37 & 33 & 70 & 36 & 27 & 63 \\
\hline Sample size & & 135 & 96 & 231 & 84 & 58 & 142 & 47 & 37 & 84 \\
\hline
\end{tabular}

\section{Descriptive statistics}

Table 2 reports the percentage of Chinese and Asian Indians who have current jobs that match their experiences prior to immigration. The sum of the"first job without subsequent change" and the "first job with subsequent change" do not equal to the "current job" number. This fact reflects the changing situation of job match over time in the country. While some respondents may have had the first job that matches their pre-immigration occupations and industries, their subsequent jobs may not match their previous experience. For others, their first job may not have matched their background but may have subsequently found jobs that are similar to the ones they had before immigration. The reported percentage is that of respondents in the particular category among all respondents of the ethnic group. The categories of "occupation and industry the same as before immigration," "occupation the same as before immigration," and "industry the same as before immigration" can have overlapping cases. Large proportions of both groups do not work in jobs that match their occupation and/or industry before immigration. Only 21 per cent of the respondents who are currently employed have a perfect match of both occupation and industry before and after immigration. This low percentage clearly shows that the current industries or occupations in which immigrants are working are usually not the same as the ones they worked in before immigration. About 31 per cent of these individuals have current occupations that match their occupations before immigration. A slightly higher percentage (34.6 per cent) is currently employed in the same type of industry as before immigration.

The results also show distinct differences between the two ethnic groups. Compared to Asian Indian immigrants, a higher percentage of Chinese immigrants hold current jobs in the same occupation and/or industry that they were in before immigration. While 24 per cent of Chinese immigrants have both occupation and industry match, only 17 per cent of Asian Indians have the same. Similarly, 35 per cent of Chinese immigrants have current occupations that match those they had before immigration, while a lower percentage ( 26.0 per cent) of Asian Indian immigrants has the same. About 38 per cent of Chinese immigrants are currently in industries that match the industries they were in before immigration, compared to only 30 per cent of Asian Indian immigrants.

Though the information on current jobs among immigrants portrays their current situation, it does not differentiate whether they have held their current jobs since they arrived or came to them after a series of job changes. In the next two panels, we focus on the first job after immigration with respect to the job change situation. The middle panel of Table 2 portrays the job match before and after immigration for individuals who have had only one job since immigration. The right panel of Table 2 reports the percentage of job matches before and after immigration for those who have had more than one job.

Regardless of whether or not they experienced job changes later, a large proportion of Asian Indians and Chinese had first jobs that were in neither the same occupation nor the same industry as their jobs before immigration. In comparing respondents who did not change jobs with those who changed jobs later, more Chinese and Asian Indians in the group who did not change jobs had first jobs that were in the same occupation and/or industry as their jobs before immigration. Among those who changed jobs later, only about 23 per cent of Chinese (100-76.6) and 27 per cent of Asian Indians (100-73) had had first jobs in the same occupation and/or industry as before immigration. 
Table 3. Logistic regression for those having the same occupation, industry, or both occupation and industry before immigration as the current job.

\begin{tabular}{|c|c|c|c|}
\hline & Occupation & Industry & $\begin{array}{l}\text { Occupation } \\
\text { and industry }\end{array}$ \\
\hline University education before immigration & $0.97(0.47)^{* *}$ & $1.01(0.41)^{* *}$ & $1.29(0.55)^{* *}$ \\
\hline Age at immigration & $0.00(0.03)$ & $-0.04(0.03)$ & $0.02(0.03)$ \\
\hline \multicolumn{4}{|l|}{ Occupation } \\
\hline Business, finance and administrative occupations & $0.22(0.45)$ & $-0.83(0.45)^{*}$ & $-1.18(0.55)^{* *}$ \\
\hline Sales and service occupations & $-2.03(0.64) * * *$ & $-0.96(0.51)^{*}$ & $-1.31(0.62) * *$ \\
\hline $\begin{array}{l}\text { Occupations unique to processing, manufacturing } \\
\text { and utilities }\end{array}$ & $-1.28(0.69)^{*}$ & $-1.31(0.62)^{*}$ & $-1.66(0.84)^{* *}$ \\
\hline \multicolumn{4}{|l|}{ Industry } \\
\hline Manufacturing and construction & $-0.23(0.55)$ & $0.62(0.52)$ & $-0.04(0.65)$ \\
\hline Finance and insurance & $-1.25(0.63)^{*}$ & $0.81(0.53)$ & $-0.31(0.69)$ \\
\hline Professional, scientific and technical services & $0.82(0.55)$ & $0.93(0.53)^{*}$ & $1.02(0.56)^{*}$ \\
\hline Female & $0.14(0.37)$ & $-0.03(0.34)$ & $0.23(0.41)$ \\
\hline University education after immigration & $1.87(0.66)^{* * *}$ & $0.80(0.58)$ & $1.69(0.73)^{* *}$ \\
\hline Duration in canada & $-0.02(0.02)$ & $-0.01(0.02)$ & $-0.06(0.02)$ \\
\hline Chinese & $0.32(0.39)$ & $0.47(0.36)$ & $0.36(0.44)$ \\
\hline Current job found through ethnic ties & $-0.90(0.47)^{*}$ & $-0.29(0.40)$ & $-0.49(0.51)$ \\
\hline Supervisor at current work & $0.33(0.43)$ & $0.21(0.41)$ & $-0.21(0.49)$ \\
\hline English use at current work & $-0.59(0.67)$ & $-0.33(0.62)$ & $-0.03(0.73)$ \\
\hline Majority of current coworkers co-ethnic & $0.07(0.67)$ & $-0.69(0.63)$ & $0.32(0.70)$ \\
\hline Majority of current clients co-ethnic & $1.83(0.65)^{*}$ & $0.29(0.55)$ & $1.26(0.64)^{*}$ \\
\hline Majority of current managers co-ethnic & $0.17(0.74)$ & $1.36(0.71)^{*}$ & $0.60(0.79)$ \\
\hline First job & $0.81(0.38)^{*}$ & $0.72(0.34)^{* *}$ & $0.76(0.43)^{*}$ \\
\hline Constant & $-1.26(1.38)$ & $-1.43(1.27)$ & $-3.58(1.59) * *$ \\
\hline Sample size & 223 & 223 & 223 \\
\hline Pseudo r-squared & 0.22 & 0.14 & 0.19 \\
\hline
\end{tabular}

Notes: $* \mathrm{p}<0.1 ; * * \mathrm{p}<0.05 ; * * * \mathrm{p}<0.01 ;$ standard errors are in parentheses.

The results of first jobs without subsequent change of Chinese and Asian Indian immigrants are similar to the findings regarding their current jobs. Among those who have not changed jobs, Chinese have a higher percentage of job matches than do Asian Indians. For example, among those who have not changed jobs, approximately 42 per cent of Chinese respondents are in the same occupation after immigration as before immigration, while only 29 per cent of Asian Indians are in that situation. These patterns are not found among those who changed jobs later.

\section{Multivariate analysis}

We examine a series of logistic regression analyses to further understand how the job match of the current job is related to factors related to before, at, and after immigration. We look at three separate analyses, and the results are reported in Table 3. The first panel of Table 3 gives the logistic regression results for the scenario of occupational match of current job with job before immigration. The middle panel gives the results for industrial sector match of current job with job before immigration. The third panel gives the results for both industrial sector and occupational match of current job with job before immigration. In this set of analyses, we are able to control for job search experience, language used in the workplace, and co-ethnic composition of the workplace, as all this information is available. However, our discussion focuses on the three factors of before, at, and after immigration.

The results show that, as in any other job search, education — especially education received overseas-is important in matching jobs before and after immigration. The effect is even stronger for jobs that match both the occupation and the industrial sector of the jobs that were held before immigration. Age at immigration does not relate to any aspect of job match for immigrants, whether occupational match, industrial sector match, or both. In addition, we found that respondents in occupations that are typical for Chinese and Asian Indian immigrants, as compared to other occupations, are less likely to have their current jobs match the jobs they had before immigration. The results suggest that while a considerable proportion of immigrants may take these jobs, they do not necessarily match the jobs they had before immigration. The participating industrial sector usually does not relate to their job match situation. 
Fong and Jiao: Job matching for Chinese and Asian Indian immigrants in Canada

Table 4. Logistic regression for those having the same occupation, industry, or both occupation and industry before immigration as the first job for those have had more than one job.

\begin{tabular}{|c|c|c|c|c|c|c|}
\hline \multirow[b]{3}{*}{$\begin{array}{l}\text { University education before } \\
\text { immigration }\end{array}$} & \multicolumn{3}{|c|}{ First job without subsequent change } & \multicolumn{3}{|c|}{ First job with subsequent change } \\
\hline & Occupation & Industry & $\begin{array}{l}\text { Occupation } \\
\text { and industry }\end{array}$ & Occupation & Industry & $\begin{array}{l}\text { Occupation } \\
\text { and industry }\end{array}$ \\
\hline & $0.94(0.49)^{*}$ & $1.21(0.46)^{* * *}$ & $1.21(0.50)^{* *}$ & $-0.74(0.90)$ & $0.08(0.78)$ & $-1.06(1.09)$ \\
\hline Age at immigration & $-0.05(0.03)$ & $0.01(0.03)$ & $0.02(0.03)$ & $0.14(0.07)^{* *}$ & $0.01(0.04)$ & $0.12(0.07)^{*}$ \\
\hline \multicolumn{7}{|l|}{ Occupation } \\
\hline $\begin{array}{l}\text { Business, finance and } \\
\text { administrative occupations }\end{array}$ & $-0.04(0.55)$ & $-1.30(0.59)^{* *}$ & $-0.90(0.62)$ & $-0.91(1.11)$ & $-0.55(0.88)^{*}$ & $-0.18(1.10)^{*}$ \\
\hline $\begin{array}{l}\text { Sales and service } \\
\text { occupations }\end{array}$ & $-1.78(0.68)^{* * *}$ & $-1.43(0.62)^{* *}$ & $-1.17(0.66)^{*}$ & $-3.96(1.45)^{* * *}$ & $-2.44(0.60)^{* * *}$ & $-0.20(1.23)^{* *}$ \\
\hline $\begin{array}{l}\text { Occupations unique to } \\
\text { processing, manufacturing } \\
\text { and utilities }\end{array}$ & $-2.29(0.83)^{* *}$ & $-1.54(0.72)^{* *}$ & $-2.25(0.95)^{* *}$ & $-1.44(1.44)$ & $-2.32(1.29)^{*}$ & \\
\hline \multicolumn{7}{|l|}{ Industry } \\
\hline $\begin{array}{l}\text { Manufacturing and } \\
\text { construction }\end{array}$ & $0.12(0.68)$ & $0.28(0.65)$ & $0.22(0.71)$ & $-2.69(1.34)^{*}$ & $-0.68(0.83)$ & $-0.01(1.05)$ \\
\hline Finance and insurance & $-1.86(0.86)^{* *}$ & $1.06(0.80)$ & $-0.89(0.91)$ & $0.53(1.99)$ & $1.16(1.89)$ & $0.03(1.10)$ \\
\hline $\begin{array}{l}\text { Professional, scientific and } \\
\text { technical services }\end{array}$ & $0.33(0.58)$ & $0.67(0.59)$ & $0.29(0.59)$ & $-0.01(1.28)$ & $0.08(1.15)$ & $0.04(0.07)$ \\
\hline Female & $0.42(0.43)$ & $0.38(0.41)$ & $0.46(0.45)$ & $-0.19(0.96)$ & $-0.69(0.76)$ & $0.08(1.15)$ \\
\hline $\begin{array}{l}\text { University education after } \\
\text { immigration }\end{array}$ & $1.91(0.79)^{* *}$ & $0.22(0.70)$ & $0.63(0.80)$ & $-0.92(1.51)$ & $0.45(0.97)$ & $-0.45(1.51)$ \\
\hline Chinese & $0.99(0.46)^{* *}$ & $0.78(0.44)^{*}$ & $0.81(0.47)^{*}$ & $-0.13(0.92)$ & $0.67(0.82)$ & $-0.01(0.08)$ \\
\hline Constant & $-1.22(1.19)$ & $-1.52(1.13)$ & $-3.645^{* *}$ & $-4.01(2.34)^{*}$ & $-0.19(1.71)$ & $0.002(2.4)$ \\
\hline Sample size & 136 & 136 & 136 & 87 & 87 & 87 \\
\hline Pseudo r-squared & 0.20 & 0.16 & 0.16 & 0.38 & 0.19 & 0.26 \\
\hline
\end{tabular}

Notes: $* \mathrm{p}<0.1 ; * * \mathrm{p}<0.05 ; * * * \mathrm{p}<0.01 ;$ standard errors are in parentheses.

The ethnic background indicator (i.e., whether respondent is Chinese) shows that job matching before and after immigration is not significantly different between Chinese and Asian Indians, as the indicator of being Chinese is not statistically significant in all three models. In other words, taken together from the results of Table 2, both Chinese and Asian Indians experience high levels of job mismatch. In addition, results from other control variables suggest that a higher co-ethnic concentration in the workplace, especially with a high concentration of co-ethnic clients and/or management, is related to a higher likelihood of job match. Immigrants work in ethnic business not only because that is where they can secure jobs, but also because it is where they can find jobs similar to the jobs they had before immigration.

However, this analysis is cross sectional and cannot address the differences in the first job experience of those whose have never changed jobs, and those who changed jobs later. That is the subject of our next analysis.

To further understand job matches before and after immigration, our next analysis focuses on the first job obtained after immigration. We divide the groups into those who have not changed jobs since they arrived and those who made changes later. Changing jobs may suggest a greater likelihood of job mismatch. Age at immigration, foreign education, and occupational type and industrial sector may have different effects on job match. In our analysis, we further control for gender and whether the respondent is Chinese or Asian Indian. We are not able to include some of the control variables that were in the previous analysis. The information was not collected in relation to first jobs. In addition, we do not include "occupations unique to processing, manufacturing, and utilities" in the model of respondents who have changed job later and both occupational and industrial job match, because cases are very small in those occupations.

For those who have not changed jobs since their arrival, higher education before immigration increases the likelihood of job match. The effect is insignificant for those who changed jobs later. For age at immigration, only immigrants not changed jobs later, the matching of their first job does not relate to the factor. The effect is important to occupational match, and both occupational and industrial match for those who have changed jobs since immigration. 
For those who changed jobs later, occupational type clearly is related to the job match of the first job with the pre-immigration job. Similar to the findings reported in the previous table, Chinese and Asian Indians in occupations with large proportions of their own groups are generally not in the occupations they were in before immigration. The findings seem to further reinforce the interpretation that the higher representation of immigrants in these occupations for their first job simply reflects that immigrants take these jobs because they are available, not because they fit their training or work experience. However, the industrial sector has a limited effect on the job match of immigrants.

\section{Conclusion}

The media often discuss job mismatch as a common job experience among immigrants. Despite this frequent portrayal, there has been little research to document the extent of the situation. In this paper, based on recently collected data from Toronto, we focus our discussion on Chinese and Asian Indians, the two major immigrant groups in the city. Our study is based on the understanding that immigrant economic adaptation is related to their experiences even before immigration, and their life course experiences before and after immigration can relate to the job match experiences. Therefore, we explore how factors before, at, and after immigration affect their job match situation.

Our study shows that a relatively small percentage of Chinese and Asian Indian immigrants work in the same industry and occupation as they did before immigrating. The percentage is even lower for Asian Indians. These findings are alarming. They suggest that a large proportion of immigrants, at least among the two largest immigrant groups in the city, are not able to fully utilize their human capital resources.

The multivariate analyses further suggest that education, even when received in a foreign country before immigration, does help immigrants to obtain current jobs in the same occupations and industries they were in before immigration. This pattern is found for the first job of those who have remained in that job since immigration. The findings clearly show that experiences before immigration can affect job attainment of immigrants. However, foreign education is not related to the first job of immigrants who changed jobs later. The findings seem to suggest that immigrants utilize their foreign education to secure jobs when they arrive, but foreign education becomes less important as they seek subsequent jobs after staying in the new country for a longer period of time.

In an economy that emphasizes skills and credentials, higher education before immigration helps immigrants secure first jobs that match their jobs before immigration. Though other studies have noted that foreign education has a discount effect on earnings and on securing jobs, our findings show that foreign higher education can help match jobs held before and after immigration. Taking these two sets of findings together, immigrants may prefer to settle in jobs similar to their jobs prior to immigration, even if their earnings are lower.

The findings consistently show that age at immigration does not relate to the job match situation. Though studies have shown that age at immigration can affect the economic attainment of immigrants, our results show that there is no effect on job match among immigrants. After all, job match is related to job availability rather than duration or how young the immigrants are when they arrive in the country.

The study has implications for the study of immigrant economic adaptation. The life course perspective on immigrant adaptation takes into consideration experiences before and after immigration, and can facilitate understanding of immigrant economic attainment in the new country. In our case, the focus is the job match experience. At the same time, future studies should differentiate gender differences, while taking life course experiences into consideration. Future studies should also explore how experiences before immigration shape the economic adaptation of immigrants. As well, the study has hinted that the economic adaptation of immigrants can be complicated. They may continue to work in the same occupational and industrial sectors that they were in before immigration, despite lower earnings. They may change jobs in order to find a job in the same occupational and industrial sectors as before immigration. In other words, economic adaptation may relate not only to maximizing economic returns, but also to matching occupational and industrial sectors before and after immigration.

This study also has some important policy implications. First, the low percentage of immigrants who can find jobs that match their work experience prior to immigration, even when they have been in the country for a period of time, is alarming. The government should address this issue. Second, some industries are more likely to accommodate the pre-immigration job experience. There should be in-depth case studies to identify the institutional mechanisms that facilitate immigrants with prior work experience in specific industries to obtain jobs in the same industries. Third, 
Fong and Jiao: Job matching for Chinese and Asian Indian immigrants in Canada

higher education, whether received in Canada or not, helps the job match of immigrants. Economic immigrant applications should place higher emphasis on educational level.

Without a doubt, this study provides only a preliminarily understanding of the job matching experiences of immigrants. Because the economic integration of immigrants and utilization of their previous job experience affect their life chances and also have significant implications for public policy, further study of the topic is urgently needed.

\section{References}

Alba, R., and V. Nee. 1997. Rethinking assimilation theory for a new era of immigration. International Migration Review 31:826-874.

- 2003. Remaking the American Mainstream: Assimilation and Contemporary Immigration. Cambridge: Harvard University Press.

Baldwin, J., and D. Beckstead. 2003. Knowledge workers in Canada's economy, 1971-2001. MIE Research Paper. Statistics Canada.

Bean, F.D., and G. Stevens. 2003. America's Newcomers and the Dynamics of Diversity. New York: Russell Sage Foundation.

Bean, F.D., R.R. Berg, and J.V.W. Van Hook. 1996. Socioeconomic and cultural incorporation and marital disruption among Mexican Americans. Social Forces 75(2):593-617.

Behrman, J.R., M.R. Rosenzweig, and P. Taubman. 1996. College choice and wages: Estimates using data on female twins. The Review of Economics and Statistics 78(4):672-685.

Bell, D. 1973. The Coming of Post-industrial Society: A Venture in Social Forecasting. New York: Basic Books.

Belman, D., and J.S. Heywood. 1991. Sheepskin effects in the returns to education: An examination of women and minorities. Review of Economics and Statistics 73(November):720-724.

Bhandari, S.B., S. Horvath, and R. To. 2006. Choices and voices of immigrant men: Reflections on social integration. Canadian Ethnic Studies 38(1):140-148.

Boyd, M. 2001. Asian engineers in Canada, in The International Migration of the Highly Skilled: Demand, Supply, and Development Consequences, edited by W.A. Cornelius and T.J. Espenshade. La Jolla, CA: Center for Comparative Immigration Studies, University of California, San Diego.

Boyd, M., and D. Thomas. 2001. Match or mismatch? The labour market performances of foreign-born engineers. Population Research and Policy Review 20:107-133.

Campion-Smith, B. 2005. Are we ready for more immigrants? Not if you talk to the people who help settle them. Toronto Star, October 11, p. A01.

Card, D., and A. Krueger. 1992. Does school quality matter: Returns to education and the characteristics of public schools in the United States. Journal of Political Economy 100(1):1-40.

Constant, A., and D.S. Massey. 2002. Return migration by German guestworkers: Neoclassical versus new economic theories. International Migration 40(4):5-38.

DaVanzo, J.S., and P.A. Morrison. 1981. Return and other sequences of migration in the United States. Demography 18:85-101.

Farley, R. 1996. The New American Reality: Who We Are, How We Got There, Where We Are Going: New York: Russell Sage Foundation.

Fong, E., and X. Cao. 2009. Effects of foreign educational earning among immigrants. Canadian Studies in Population 36(1-2):87-110.

Gans, H.J. 1997. Toward a reconciliation of "assimilation" and "pluralism:" The interplay of accultural and ethnic retention. International Migration Review 31:875-892.

- 2009. First generation decline: Downward mobility among refugees and immigrants. Ethnic and Racial Studies 32(9):1658-1670.

Granovetter, M.S. 1973. The strength of weak ties. American Journal of Sociology 78:1360-1380.

Jaeger, D.A., and M.E. Page. 1996. Degrees matter: New evidence on sheepskin effects in the returns to education. The Review of Economics and Statistics 78(4):733-740. 
Kim, C., and A. Sakamoto. 2010. Have Asian American men achieved labor market parity with white men? American Sociological Review 75(6):934-957.

Kim, N.K. 2008. Imperial Citizens: Koreans and Race from Seoul to LA. Stanford, CA: Stanford University Press.

Lee, S.M., and B. Edmonston. 2011. Age-at-arrival's effects on Asian immigrants' socioeconomic outcomes in Canada and the US. International Migration Review 45(3):527-561.

Li, P.S. 2000. Earning disparities between immigrants and native-born Canadians. Canadian Review of Sociology and Anthropology 37(3):289-310.

- 2001. The market worth of immigrants' educational credentials. Canadian Public Policy 27:23-38.

- 2003. Initial earnings and catch-up capacity of immigrants. Canadian Public Policy 29(3):319-337.

Montgomery, J.D. 1992. Job search and network composition: Implications of the strength-of-weak-ties hypothesis. American Sociological Review 57(5):586-596.

Myers, D., and C.J. Cranford. 1998. Temporal differentiation in the occupational mobility of immigrant and nativeborn Latina workers. American Sociological Review 63(1):68-93.

Myers, D., X. Gao, and A. Emeka. 2009. The gradient of immigrant age-at- arrival effects on socioeconomic outcomes in the US. International Migration Review 43(1):205-229.

Park, J.H. 1999. Estimation of sheepskin effects using the old and the new measures of educational attainment in the Current Population Survey. Economic Letters 62(2):237-240.

Park, K. 1997. The Korean American Dream: Immigrants and Small Business in New York City. Ithaca, NY: Cornell University Press.

Piore, M.J. 1979. Birds of Passage: Migrant Labor and Industrial Societies. New York: Cambridge University Press.

Portes, A., and R. Schauffler. 1994. Language and the second generation: Bilingualism yesterday and today. The New Second Generation. Special issue, International Migration Review 28(4):640-661.

Reitz, J.G. 1999. Warmth of the Welcome: The Social Causes of Economic Success for Immigrants in Different Nations and Cities Boulder: Westview Press

- 2011. Taxi driver syndrome. Literary Review of Canada 19(2):20-22.

Rumbaut, R.G. 2004. Ages, life stages, and generational cohorts: Decomposing the immigrant first and second generations in the United States. International Migration Review 38(3):1160-1205.

- 2008. The coming of the second generation: Immigration and ethnic mobility in Southern California. The Annals of the American Academy of Political and Social Science 620:196-236.

Sakamoto, A., K.A. Goyette, and C. Kim. 2009. Socioeconomic attainments of Asian Americans. Annual Review of Sociology 35(1):255-276.

Salaff, J.W., S. Wong, and A. Greve. 2010. Hong Kong Movers and Stayers: Narratives of Family Migration. Urbana, IL: University of Illinois Press.

Sanders, J.M., and V. Nee. 1987. Limits of ethnic solidarity in the enclave economy. American Sociological Review 52:745-767.

Santiago, C.E. 1993. Friends or strangers: The impact of immigrants on the US economy. Industrial \& Labor Relations Review 46(4):731.

Shibuya, K., E. Fong, M-L. Lam, and C. So. 2001. Return migration among Chinese immigrants in Toronto, in The Chinese Triangle of Mainland China, Taiwan, and Hong Kong: Comparative Institutional Analyses, edited by A. So, N. Lin, and D. Poston. Westport, CT: Greenwood Press.

Statistics Canada. 2001. A Portrait of Early Settlement Experiences. Catalogue No. 89-614-XPE.

Tang, J. 1993. The career attainment of Caucasian and Asian engineers. Sociological Quarterly 34(3):467-496.

White, M.J., and J.E. Glick. 2009. Achieving Anew: How New Immigrants Do in American Schools, Jobs, and Neighborhoods. New York: Russell Sage Foundation.

Zeng, Z., and Y. Xie. 2004. Asian-Americans' earnings disadvantage reexamined: The role of place of education. American Journal of Sociology 109(5):1075-1108.

Zhou, M. 1992. Chinatown: The Socioeconomic Potential of an Urban Enclave. Philadelphia: Temple University Press. 